\title{
Influence of Turgor on Micromechanical and Structural Properties of Apple Tissue
}

\author{
Oey, M.L., Vanstreels, E., De Baerdemaeker, J., Tijskens, E., Ramon, H., Nicolaï, B. \\ BIOSYST - MeBioS, Faculty of Bioscience Engineering, Katholieke Universiteit Leuven, \\ W. de Croylaan 42, 3001 Leuven, Belgium. Phone: +32 16322668 - Fax: +32 16322955. \\ E-mail: mailin.oey@biw.kuleuven.be
}

\begin{abstract}
The effect of turgor on the micromechanical properties of apples (Malus domestica $\mathrm{cV}$ 'Jonagored') and its relation to structural parameters of the cells was investigated. Mechanical measurements were carried out using a miniature tensile stage mounted under a microscope. Turgor was manipulated by soaking tissue samples in iso-, hypo- or hypertonic mannitol solutions. Samples were then subjected to tensile and compression tests, during which the deformation of the individual cells was recorded. In both tests, sigmoidal stressstrain curves were found, where stiffness increases with strain. With increasing turgor, strain at maximum stress became significantly $(\mathrm{p}<0.05)$ lower while stiffness increased, but no clear effect on failure stress was found. As expected, fresh apples proved to be firmer and stiffer than stored apples, while the influence of turgor was the same. Measurement of initial cell parameters (area, length, width, aspect, roundness) showed that the apples in the experiment were homogeneous, having comparable cell sizes. Manipulation of turgor did not affect initial cell parameters, but the magnitude of cell deformations was clearly influenced. Larger deformations were found in flaccid cells. Changes in length and width were closely related to strain measurements. In conformity with micromechanical parameters, deformations were smaller in stored compared to fresh apples.
\end{abstract}

Keywords: micromechanics, turgor, cell structural parameters, apple tissue

\section{Introduction}

Texture is one of the primary quality attributes of fruits and vegetables and is determined by the mechanical properties of the tissue which are affected by factors as ripening stage and water status. These properties also determine the susceptibility to mechanical damage that can impart during harvest, transport and storage, and that eventually leads to a loss of commercial value.

Texture of fruits is commonly evaluated based on the macroscopic mechanical properties of the whole fruit. However, fruits are not a continuous material, but consist in fact of a complex conglomerate of cells. The macroscopic mechanical properties of the tissue are thus determined by various microscopic cellular and histological features, such as cell size, amount of intercellular space, mechanical properties of the cell wall and middle lamella, and turgor pressure. A micromechanical approach is therefore preferable to understand the relative importance of these features on the overall mechanical behaviour of fruits.

A determining factor for fruit firmness is the cell wall structure of the tissue. Plant cell walls are composed of cellulose microfibrils embedded in a matrix of pectins and he micelluloses or lignin. During fruit ripening, the cell wall structure is partly dissolved as enzymatic degradation of the cell walls takes place, which results in softening of the tissue (Hertog et al., 2004). Besides cell wall structure, turgor pressure is thought to have major influence on tissue strength and macroscopic fruit firmness. It is exerted by intracellular liquids on the 
cellular membrane and cell wall and imparts turgidity, rigidity, crispness and a fresh appearance to the plant tissue. Turgor is lost when fruits or vegetables are deprived of water, through transpiration, or when they cease to respire. As a consequence, the tissue begins to wilt, accompanied by a dry appearance through loss of gloss and colour (Aguilera and Stanley, 1999).

To study the effects of turgor, it can be manipulated by soaking fruit discs in solutions of different osmotic concentrations. In general, turgor pressure increases by water uptake after incubation in solutions that are less concentrated than the cell sap (hypotonic solutions), and decreases when water is released during soaking in hypertonic solutions (more concentrated than the cell sap). This can be measured by changes in weight and volume (Lin and Pitt, 1986). Influence of turgor on mechanical parameters of fruit or vegetable tissue has been investigated using a number of different test methods, obtaining different results. In studies on potato and apple using uniaxial compression, increased turgor led to tissue failure at lower stresses and shorter strains, while the initial modulus increased (Lin and Pitt, 1986; Konstankiewicz and Zdunek, 2001a; Scanlon et al., 1996). This has been related to higher turgidity pre-stressing and weakening of the cell walls, making the tissue more brittle. Also puncture force and deformation of tomatoes decreased when turgor was increased above that of untreated tissue (Jackman et al., 1992). In studies on apples during storage, using cutting tests and three point bending tests no effect of turgor could be detected when turgor was controlled (Alvarez, 2000). In tensile tests on pear specimen, turgor did not affect force at failure in soft tissue, which was explained by cell-to-cell debonding at the middle lamella being the predominant failure mode. In firm pears, however, the force necessary for tissue rupture increased with higher turgor suggesting stress-hardening of the cell wall (De Belie et al., 2000).

Knowledge of the relationship between tissue level (macroscale) deformations and cellular (microscale) deformations is a prerequisite for the development of mathematical models predicting mechanical behaviour of plant tissue. Therefore, a method for simultaneous observation of cell parameters in the tissue in relation to micromechanical properties has been developed in our laboratory for onion epidermis (Vanstreels et al., 2005) and for apple tissue (Alamar et al., 2005). In the latter, the effect of cell size on micromechanical parameters was examined using two different apple cultivars.

In the present work influence of turgor is combined with a comprehensive investigation of micromechanical properties of apple tissue in relation to cellular deformations. The effect of test method (tensile and compression), effect of ripening stage (fresh and stored apples) as well as effect of turgor pressure (high, normal and low) will be considered. The results will be valuable when developing detailed mathematical models $\mathbf{b}$ describe behaviour of plant tissue under mechanical loading.

\section{Material and methods}

\subsection{Samples}

Apples (Malus domestica Borkh cv 'Jonagored') were harvested at optimal harvest time at the experimental station PCFruit-PPS in Velm (Belgium) and kept under optimal storage conditions $\left(0.8^{\circ} \mathrm{C} ; 2.5 \% \mathrm{CO}_{2} ; 1 \% \mathrm{O}_{2}\right)$ until use. Fruits for experiments were taken either directly from optimal storage conditions (fresh fruits) or they were kept for 12 days at $18^{\circ} \mathrm{C}$ to simulate shelf life conditions (stored fruits). Fruits were selected according to absence of blemishes and defects, and their uniformity in size and firmness. The average Magnus-Taylor firmness of fresh and stored apples was $79 \mathrm{~N}$ and $67 \mathrm{~N}$ respectively. The isotonic point of the two lots was determined as described by Lin and Pitt (1986). Samples were cut radially from 
the parenchyma in form of ectangular specimen $(11 \mathrm{~mm}$ length $\mathrm{x} 5 \mathrm{~mm}$ width $\mathrm{x} 2 \mathrm{~mm}$ height for tensile tests; $3 \mathrm{~mm} \times 11 \mathrm{~mm} \times 5 \mathrm{~mm}$ for compression tests) using parallel razor blades. Special attention was given to take samples from the green side of the apples, avoiding the tissue close to the skin and the core. To manipulate cell turgor, samples were immersed overnight in isotonic $(0.65 \mathrm{M})$, hypotonic $(0.45 \mathrm{M})$ and hypertonic $(0.85 \mathrm{M})$ mannitol solutions. Samples were stained for 2 min with methylene blue $(7.5 \mathrm{mg} / 100 \mathrm{ml})$ directly before mechanical testing to allow visualisation of the cells during the tests.

\subsection{Mechanical Tests and Image Analysis}

Mechanical testing was carried out using a miniature tensile stage (Deben Microtest, Suffolk, U.K.) equipped with grips for either tensile or compression tests (Figure 1). The tensile stage was placed underneath a stereomicroscope (SMZ1000, Nikon, Japan) equipped with a CCD camera (type TK-1360B colour $1 / 2$ inch CCD, JVC). This allowed monitoring the deformation of individual cells while simultaneously recording the corresponding forcedisplacement curves.

In total 15 fresh and 15 stored apples were taken for experiments. For each apple tested, 3 specimens were cut for tensile and 3 specimens for compression tests. The specimens were immediately put in the three different mannitol solutions for overnight soaking. To keep the same strain rate in either test, testing speeds was set to $0.5 \mathrm{~mm} / \mathrm{min}$ for tensile and to 0.2 $\mathrm{mm} / \mathrm{min}$ for compression tests. For tensile tests samples needed to be glued to the grips of the miniature tensile stage by a cyanoacrylate adhesive. Beyond a certain travel 3 cyclic tests were carried out, and then samples were further elongated or compressed until tissue failure.

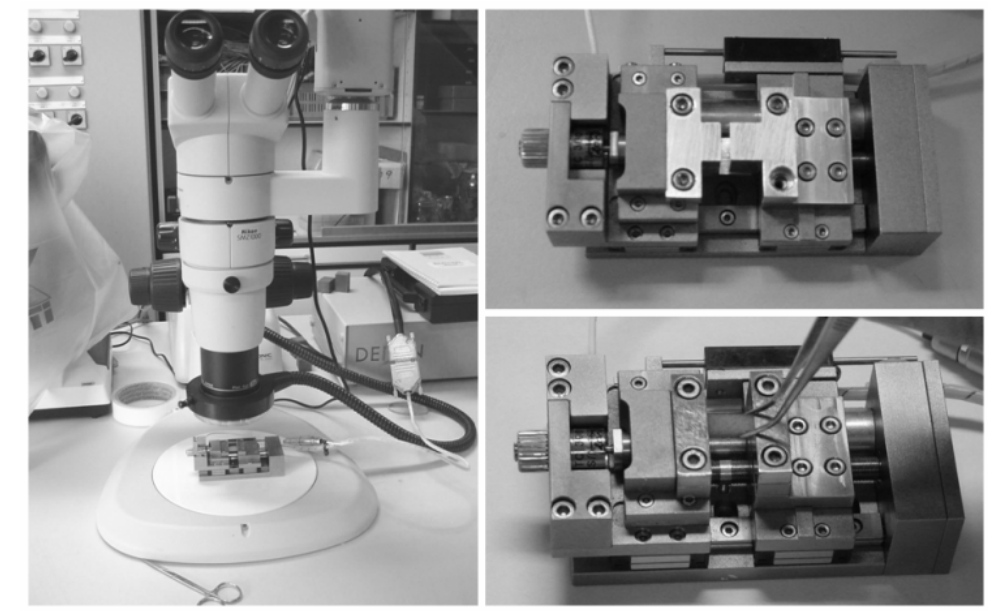

Figure 1: Microtensile stage underneath the microscope (left) and as close-up with grips used for compression tests (top right) and for tensile tests (bottom right).

After a digitisation step in a custom-made Matlab program (MATLAB 6.5, The MathWorks, Inc., Natick, MA, USA), it was possible to analyse images by means of image analysing software (Image-Pro Plus 4.5, Media cybernetics, Silver Spring, USA). An example of images before and after digitisation can be seen in Figure 2. Cell structural parameters were extracted from the first image and at the point where $80 \%$ of the maximal stress was attained, so that cell deformations could be calculated. Analysed parameters included area, aspect, roundness (perimeter ${ }^{2} / 4 \times \pi \times$ area), perimeter, length and width. Length and width were calculated from a box which was fitted around the cells; the length of the box pointed in the same direction as the mechanical load, and width perpendicular to it. The percentage deformation of cell structural parameters was calculated as follows $\left(X_{\text {initial }}-X_{80 \%}\right) / X_{\text {initial }} \times 100$. 


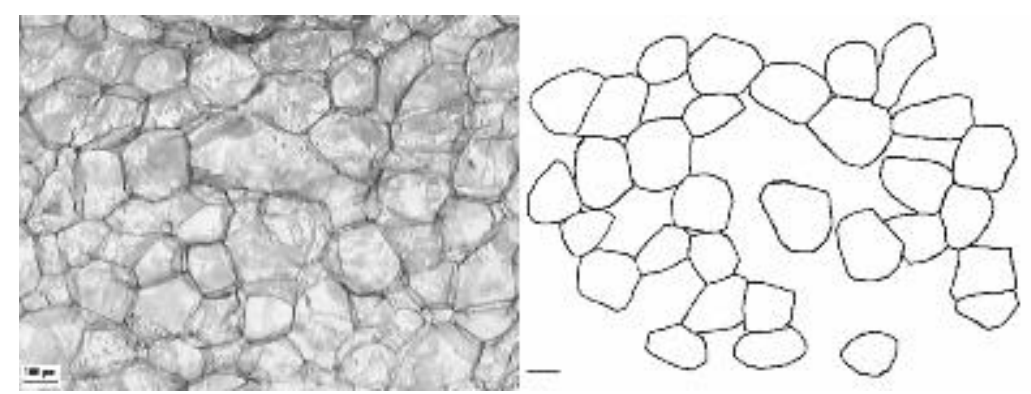

Figure 2: Apple cells as observed beneath the stereomicroscope (left) and after digitisation as vectorised image (right). Scale bar represents $100 \mu \mathrm{m}$.

\subsection{Data analysis}

Force-deformation data were converted to stress-strain data. The micromechanical parame ters maximum stress $\left(\mathrm{s}_{\max }\right)$, strain at failure $\left(\mathrm{e}_{\max }\right)$ were extracted; the modulus of elasticity at start (initial modulus $\left.\mathrm{E}_{\mathrm{nitial}}\right)$ and at approx. $80 \%$ stress $\left(\mathrm{E}_{80 \%}\right)$ was calculated as the slope of the stress-strain curve.

Statistical analysis was carried out using the general linear model procedure in SAS (SAS version 8 , SAS Institute Inc., Cary, NC, USA).

\section{Results and Discussion}

\subsection{Cell Parameters}

Cell size of apples varies considerably depending on the cultivar. Since the aim of this experiment was to investigate the effect of turgor, only one apple cultivar (Jonagored) was used and fruits of comparable sizes were selected in order to minimize the effect of cell dimensions on micromechanical behaviour. Results of cell parameter measurements (Table 1) show that the cell size in the tested tissue samples was homogenous throughout the different apples.

Table 1: Means and standard errors of initial cell structural parameters of apple tissue under different turgor pressures (high, normal, low). Significant differences $(\mathbf{p}<0.05)$ are indicated by different letters within one row.

\begin{tabular}{llccc}
\hline Turgor & & high & normal & low \\
\hline Area $\left[\mu \mathrm{m}^{2}\right]$ & fresh & $23500 \pm 773^{\mathrm{a}}$ & $22767 \pm 733^{\mathrm{a}}$ & $23807 \pm 773^{\mathrm{a}}$ \\
& stored & $23311 \pm 733^{\mathrm{a}}$ & $21772 \pm 733^{\mathrm{a}}$ & $22290 \pm 788^{\mathrm{a}}$ \\
Length $[\mu \mathrm{m}]$ & fresh & $187.2 \pm 3.9^{\mathrm{a}}$ & $188.2 \pm 3.7^{\mathrm{a}}$ & $190.7 \pm 3.9^{\mathrm{a}}$ \\
& stored & $190.5 \pm 3.7^{\mathrm{a}}$ & $178.7 \pm 3.7^{\mathrm{b}}$ & $179.6 \pm 3.9^{\mathrm{b}}$ \\
Width $[\mu \mathrm{m}]$ & fresh & $173.7 \pm 3.3^{\mathrm{a}}$ & $167.4 \pm 3.2^{\mathrm{a}}$ & $170.2 \pm 3.3^{\mathrm{a}}$ \\
& stored & $172.1 \pm 3.2^{\mathrm{a}}$ & $170.2 \pm 3.2^{\mathrm{a}}$ & $167.9 \pm 3.3^{\mathrm{a}}$ \\
Aspect & fresh & $1.11 \pm 0.02^{\mathrm{a}}$ & $1.15 \pm 0.02^{\mathrm{a}}$ & $1.14 \pm 0.02^{\mathrm{a}}$ \\
& stored & $1.14 \pm 0.02^{\mathrm{a}}$ & $1.08 \pm 0.02^{\mathrm{a}}$ & $1.10 \pm 0.02^{\mathrm{a}}$ \\
Perimeter $[\mu \mathrm{m}]$ & fresh & $564.3 \pm 9.9^{\mathrm{a}}$ & $558.0 \pm 9.4^{\mathrm{a}}$ & $567.0 \pm 9.9^{\mathrm{a}}$ \\
& stored & $567.8 \pm 9.4^{\mathrm{a}}$ & $546.3 \pm 9.4^{\mathrm{a}}$ & $545.4 \pm 10.1^{\mathrm{a}}$ \\
Roundness & fresh & $1.16 \pm 0.01^{\mathrm{a}}$ & $1.17 \pm 0.01^{\mathrm{a}}$ & $1.16 \pm 0.01^{\mathrm{a}}$ \\
& stored & $1.19 \pm 0.01^{\mathrm{a}}$ & $1.17 \pm 0.01^{\mathrm{b}}$ & $1.15 \pm 0.01^{\mathrm{c}}$ \\
\hline
\end{tabular}

Nieto et al. (2004) and Salvatori and Alzamora (2000) have shown that in the initial phase of an osmotic process using a hypertonic solution, apple tissue collapses and cell walls fold and deform. After $200 \mathrm{~min}$ of osmosis, however, the cells recover their original rounded shape. 
This has been attributed partially to a multicomponent diffusion process occurring during osmosis, partially to the relaxation of structural stresses of the compressed viscoelastic cell walls. In osmotic processes in the other direction, however, the volume of the protoplast during water uptake is restricted by the cell wall and its extensibility (Alvarez et al., 2000). In our study, we compared the dimensions of the cells after immersing them overnight in osmotic solutions of different concentrations. No significant differences were found between the shapes of cells of fresh apples soaked in iso-, hypo- or hypertonic solutions. This suggests on the one hand that cell walls have a high strength with little extensibility in the case of water uptake, on the other hand that cells recover after stressing by water release. In case of stored apples, differences were found for the parameters length and roundness. Cells soaked in hypotonic solutions (high turgor) are significantly longer; their cell walls exhibit thus a certain extensibility, which is probably due to degradation of the cell wall during storage. Correspond ing to the increased length, cells with high turgor are less round, and the highest roundness was found for cells soaked in hypertonic solutions. Other cell parameters of stored apples were not affected by turgor.

\subsection{Micromechanical Parameters}

Typical stress-strain curves of apple tissue under tensile and compressive loading are displayed in Figure 3.
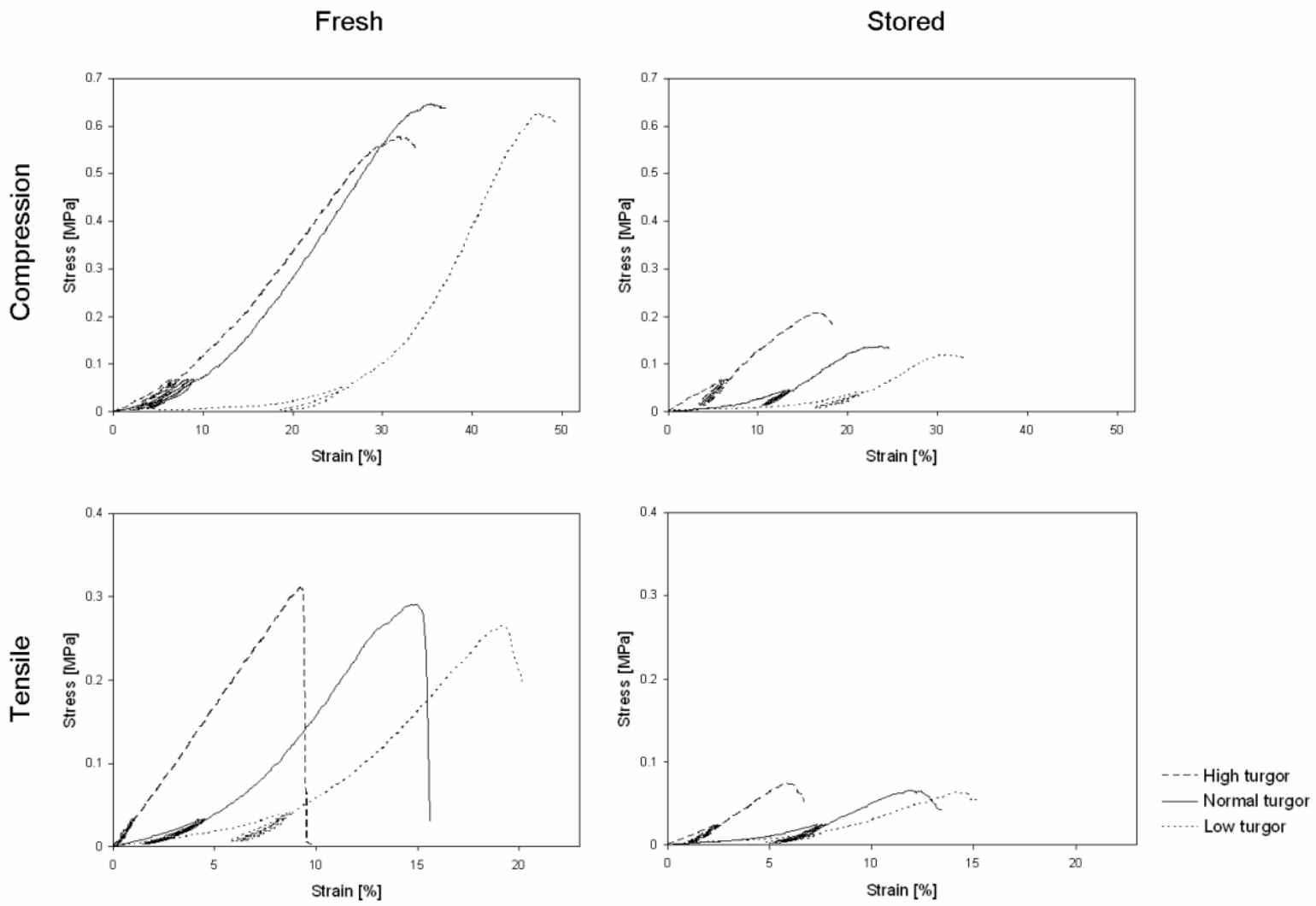

Figure 3: Typical stress-strain curves of fresh and stored apple tissue with different turgor pressures (high, normal, low) under compressive and tensile loading.

\section{Compression Tests}

The stress-strain curves produced in compression tests are S-shaped. The stiffness is small for small strains and increases when strain gets larger. In turgid tissue, this behaviour is not very apparent, but in tissue with low turgor the 'lag-phase' becomes longer, such that the 
curves are shifted to the right; the S-shape is thus more pronounced. Loading and unloading to zero stress of the samples shows that a plastic deformation remains in the material and the plastic deformation increases when turgor decreases. These characteristic stress-strain curves can be observed for both, fresh and stored, tissues; however, the stresses and strains reached in tissue of stored fruit are smaller.

This behaviour is reflected in the micromechanical parameters extracted from the curves (Table 2). Maximum strain values increase significantly with decreasing turgor. Soaking in hypertonic $(0.85 \mathrm{M})$ solutions causes the cells to release water and thus the tissue to lose its rigidity. Soaking in hypotonic $(0.45 \mathrm{M})$ solutions, however, provokes failure at smaller strains as the cells take up water; the tissue becomes thus less compliant. The initial stiffness and stiffness at higher strain of fresh samples is significantly influenced, though in opposite ways. In flaccid tissue, the initial stiffness was found to be smaller than in turgid tissue; at $80 \%$ strain, however, the stiffness was higher. In the first phase of the test, unpressurised cells can deform without developing a significant stress. Under higher strains, force is then built up in a shorter period, leading to a higher modulus. In stored tissue, stiffness was not clearly influenced by turgor manipulation. However, a slight trend was found that initial stiffness and stiffness at $80 \%$ strain are smaller in tissue with low turgor.

Table 2: Means and Standard errors of micromechanical properties of apple tissue with different turgor pressures (high, normal, low) produced in compression tests. Significant differences $(p<0.05)$ are indicated by different letters wi thin one row.

\begin{tabular}{lcccc}
\hline & & \multicolumn{3}{c}{ Compression test } \\
\cline { 3 - 5 } & & High turgor & Normal turgor & Low turgor \\
\hline $\mathrm{s}_{\max }[\mathrm{MPa}]$ & fresh & $0.58 \pm 0.02^{\mathrm{a}}$ & $0.66 \pm 0.02^{\mathrm{b}}$ & $0.65 \pm 0.02^{\mathrm{b}}$ \\
& stored & $0.21 \pm 0,02^{\mathrm{a}}$ & $0.16 \pm 0.02^{\mathrm{b}}$ & $0.12 \pm 0.02^{\mathrm{b}}$ \\
$\mathrm{e}_{\max }[\%]$ & fresh & $33.1 \pm 1.04^{\mathrm{a}}$ & $36.6 \pm 1.01^{\mathrm{b}}$ & $46.1 \pm 1.01^{\mathrm{c}}$ \\
& stored & $16.6 \pm 1.01^{\mathrm{a}}$ & $24.1 \pm 1.01^{\mathrm{b}}$ & $34.7 \pm 1.01^{\mathrm{c}}$ \\
$\mathrm{E}_{1}[\mathrm{MPa}]$ & fresh & $0.60 \pm 0.06^{\mathrm{a}}$ & $0.31 \pm 0.06^{\mathrm{b}}$ & $0.08 \pm 0.06^{\mathrm{c}}$ \\
& stored & $0.92 \pm 0.06^{\mathrm{a}}$ & $0.16 \pm 0.06^{\mathrm{b}}$ & $0.06 \pm 0.06^{\mathrm{b}}$ \\
$\mathrm{E}_{2}[\mathrm{MPa}]$ & fresh & $2.31 \pm 0.1^{\mathrm{a}}$ & $3.28 \pm 0.1^{\mathrm{b}}$ & $4.24 \pm 0.1^{\mathrm{c}}$ \\
& stored & $1.65 \pm 0.1^{\mathrm{a}}$ & $1.43 \pm 0.1^{\mathrm{a}}$ & $1.02 \pm 0.1^{\mathrm{b}}$ \\
\hline
\end{tabular}

In conformity with other studies, a smaller stress and strain was necessary to induce failure of fresh tissue with higher turgor (Konstankiewicz and Zdunek, 2001; Scanlon et al., 1996.). This can be attributed to an increase in the initial tension of the cell walls by increase of turgor. When the plant tissue is compressed, intercellular pressure increases together with the tension in the cell walls, leading to cracking at smaller stresses (Konstankiewicz and Zdunek, 2001). This behaviour was related to cell rupture as predominant failure mode (Lin and Pitt, 1986).

In agreement with previous experiments carried out in our lab (Alamar et al., 2005), considerable smaller stress and strain values were found for stored apples. During storage the pectic substances of the middle lamella and cell wall undergo solubilisation, their effect as cementing materials is therefore reduced and softening and cell separation is favoured (Kunzek, 1999). However, turgor did not affect the stress at failure in the same way. In stored apples, high turgor led to higher failure stresses than in tissue with normal or low turgor. This might be due to the smaller roundness found in turgid cells of stored tissue. The contact surface between adjacent cells is thus increased and might have led to an increase in middle lamella cross-linking and bond strength (Jackman et al., 1992). A higher load can thus be applied on turgid tissue until failure is induced. For that case, cell debonding was described as predominant mechanism of failure (Lin and Pitt, 1986). After soaking of stored 
apple samples in hypertonic solutions no effect on maximum stress was observed, neither positive nor negative, as compared to tissue under normal turgor.

\section{Tensile Tests}

Stress-strain curves produced by tensile testing exhibit a similar behaviour as curves in compression tests. The 'lag-phase' increases with decreasing turgor. In fresh samples with high turgidity, however, the relation of stress and strain was found to be linear, exhibiting no 'lag-phase'. Fresh, high turgor tissue thus behaves like an idealelastic material. In tissue with normal or low turgor, however, a certain plastic deformation remains after cyclic testing. Furthermore, the lag-phase becomes apparent again, being longer for flaccid tissue and, as a consequence, the curves are shifted to the right. Compared to compression tests, considerable lower values for stress and strain were obtained in tensile testing.

Table 3: Means and Standard errors of micromechanical properties of apple tissue with different turgor pressures (high, normal, low) produced in tensile tests. Significant differences $(p<0.05)$ are indicated by different letters wi thin one row.

\begin{tabular}{lcccc}
\hline & & \multicolumn{3}{c}{ Tensile test } \\
\cline { 3 - 5 } & & High turgor & Normal turgor & Low turgor \\
\hline $\mathrm{s}_{\max }[\mathrm{MPa}]$ & fresh & $0.33 \pm 0.01^{\mathrm{a}}$ & $0.31 \pm 0.01^{\mathrm{a}}$ & $0.29 \pm 0.01^{\mathrm{a}}$ \\
& stored & $0.07 \pm 0.01^{\mathrm{a}}$ & $0.07 \pm 0.01^{\mathrm{a}}$ & $0.07 \pm 0.01^{\mathrm{a}}$ \\
$\mathrm{e}_{\max }[\%]$ & fresh & $8.8 \pm 0.63^{\mathrm{a}}$ & $15.8 \pm 0.61^{\mathrm{b}}$ & $19.5 \pm 0.61^{\mathrm{c}}$ \\
& stored & $4.6 \pm 0.61^{\mathrm{a}}$ & $12.3 \pm 0.61^{\mathrm{b}}$ & $14.6 \pm 0.61^{\mathrm{c}}$ \\
$\mathrm{E}_{1}[\mathrm{MPa}]$ & fresh & $3.63 \pm 0.19^{\mathrm{a}}$ & $0.93 \pm 0.19^{\mathrm{b}}$ & $0.39 \pm 0.19^{\mathrm{c}}$ \\
& stored & $1.83 \pm 0.19^{\mathrm{a}}$ & $0.18 \pm 0.19^{\mathrm{b}}$ & $0.14 \pm 0.19^{\mathrm{b}}$ \\
$\mathrm{E}_{2}[\mathrm{MPa}]$ & fresh & $3.95 \pm 0.1^{\mathrm{a}}$ & $3.46 \pm 0.1^{\mathrm{b}}$ & $2.78 \pm 0.1^{\mathrm{c}}$ \\
& stored & $1.88 \pm 0.1^{\mathrm{a}}$ & $1.16 \pm 0.1^{\mathrm{b}}$ & $0.98 \pm 0.1^{\mathrm{b}}$ \\
\hline
\end{tabular}

The effect of turgor on micromechanical parameters in tensile tests (Table 3) corresponds partially to its effect found in compression tests: The filure strain increases and the initial stiffness decreases with decreasing turgor. In contrast to compression tests, the stiffness decreases also at higher strains when turgor is lowered. For failure stress, a slight increase with turgor was found, but differences are not significant. This finding is in contrast with results on pears, where a profound positive influence was found on the strength of firm fruits (De Belie et al., 2000). The increase of strength was attributed to stress-hardening through turgor, and resulted in rupturing of individual cells. Tensile strength of soft pears, however, has been independent of turgor, and has been related to cell-to-cell debonding at the middle lamella. But, in our study, stress-strain curves of fresh apples show an abrupt decrease in force at failure. This kind of behaviour is characteristic for cell rupture. The connections between the cells through the middle lamella are thus too strong to tear cells apart. For fresh apples, failure is independent from turgor, and only depends on the strength of the cell wall. However, the cell wall does not seem to be altered by manipulation of turgor through water uptake or water release. Neither occurs stress-hardening, nor pre-stressing which results in enhanced brittleness. Or, if an alteration of the cell wall by turgor manipulation takes place, it cannot be detected using the tensile test.

During storage, adhesion between the cells is reduced due to pectin solubilisation in the middle lamella. The subsequent loss of structural integrity together with a loss of cell fluids by exudation causes the considerable lower stiffness in stored apples (Varela et al., 2005). This explains why stress and strain values found for stored apples were lower as compared to fresh apples. However, influence of turgor was the same: strain increases and stiffness decreases when turgor is reduced, and no significant effect was found on failure stress. But, 
at failure, force declines slowly, not in a sudden drop. This is characteristic for cell-to-cell debonding. Using scanning electron microscopy, Tu et al. (2000) observed a clear separation of apple cells when the tissue had a tensile strength of $0.06-0.08 \mathrm{MPa}$. This corresponds to the values we obtained for tensile strength of stored apples. Hence, fr stored apples, tissue failure in tensile tests can be attributed to cell-to-cell debonding, and the point at which failure occurs is determined by the strength of the middle lamella, not by turgor.

\subsection{Cell deformations}

Figure 4 gives an example of images of apple tissue before testing and at approx. $80 \%$ stress in tensile and compression tests with the corresponding stress-strain curves. The percentage deformations of cellular parameters obtained after digitisation of the images are displayed in Figure 5.

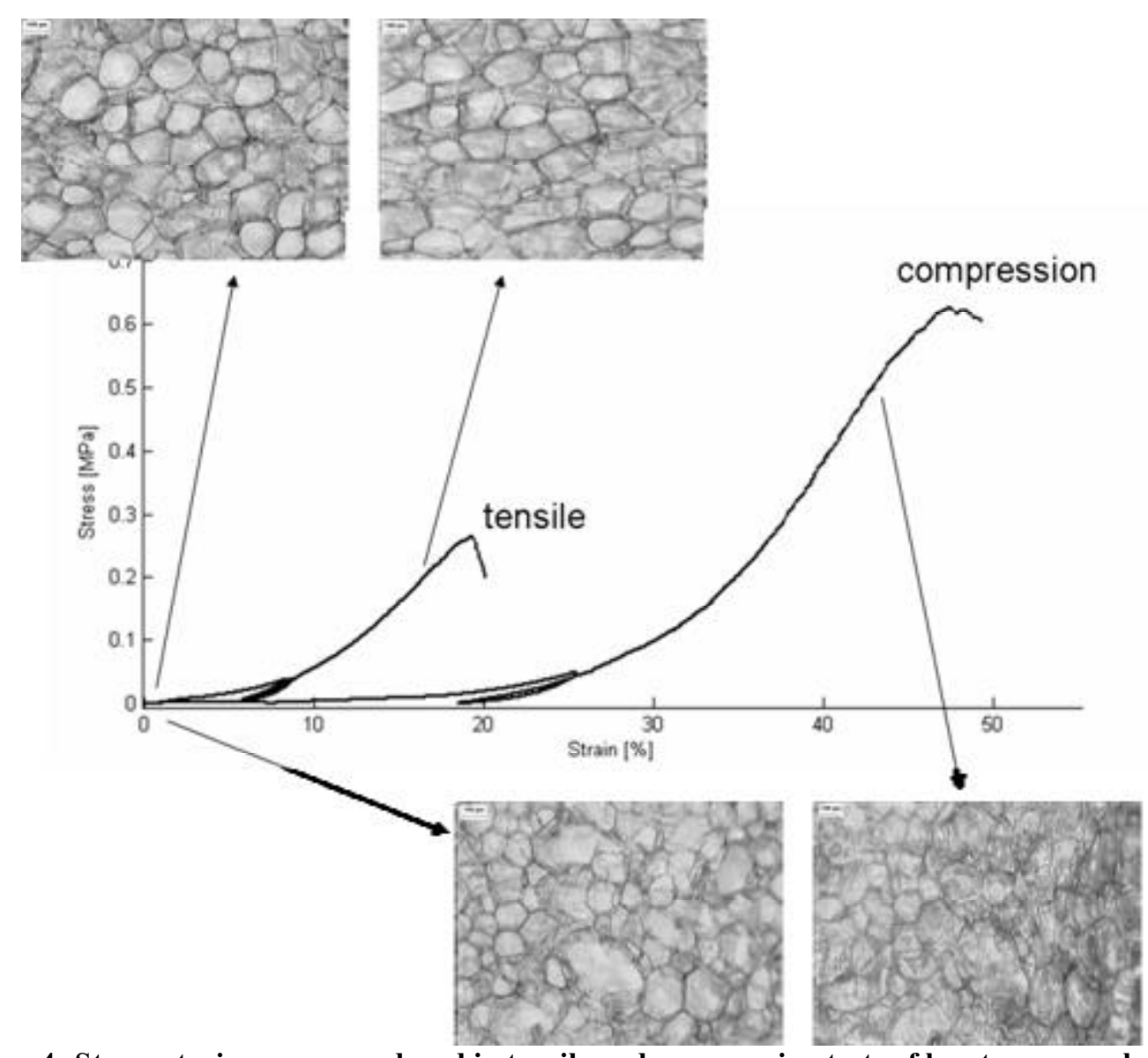

Figure 4: Stress-strain curves produced in tensile and compression tests of low-turgor apple tissue $(0.85 \mathrm{M})$ and corresponding images of the tissue at start and at $80 \%$ stress.

Considerable variation was found for deformations of individual cells under compressive or tensile loading, even within the same tissue. Nevertheless, a clear influence of turgor on some parameters could be observed. These parameters imply length and width, and therewith aspect (ratio ength/width). In tensile tests, cells became significantly longer and thinner when the tissue had low turgor; cells in flaccid tissue thus undergo larger deformations than cells in turgid tissue at similar stress levels. The same effect was observed for compression tests, but in the inverse direction: Cells become wider and shorter. Influence of turgor was, however, not as explicit as in tensile tests. Shortening of cells in the tissue was not significant different among the three turgor classes. Concerning width, deformation in turgid samples was smaller, but no difference was found between cells with normal and low turgor. 
Although area and perimeter do not necessarily change when cells undergo deformation in length and width, both parameters became smaller in compression and rather larger in tensile tests. Since cell liquid is compressible only to a limited extent, a change in area has to be associated with an increase or decrease of the cell depth. Unfortunately, it was not possible to measure the cell depth. Therefore, no information about changes in cell volume could be obtained. However, a clear influence of turgor on area and perimeter was not found in either test. Roundness of cells gets lost in both kinds of testing, which is reinforced when turgor is reduced. This effect is, however, not found for fresh apples under compression.
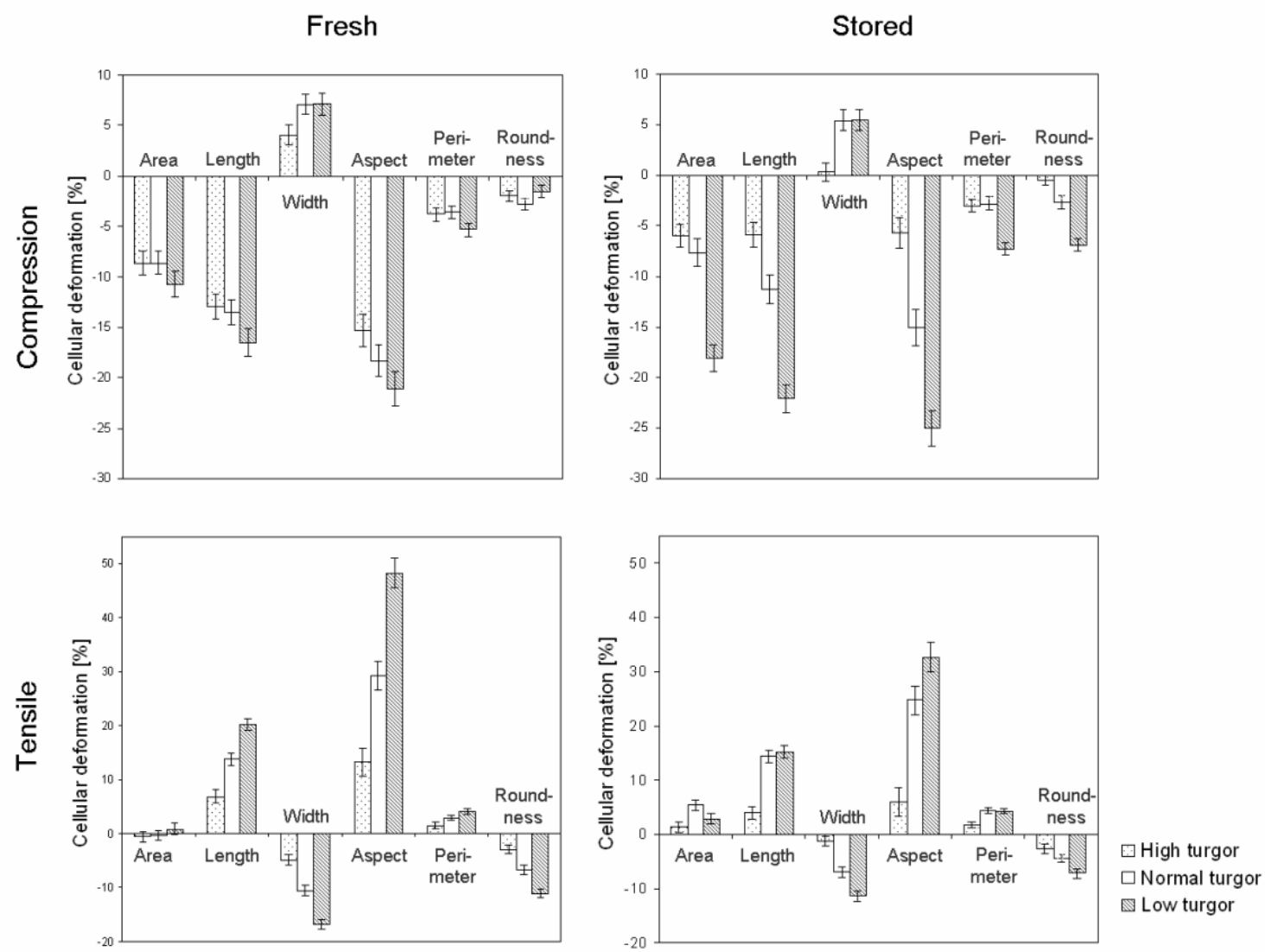

Figure 5: Percentage deformations of cell structural parameters of fresh and stored apple tissue at different turgor pressures (high, normal, low) in tensile and compression tests. The bars represent standard errors.

For tissue of stored apples, the influence of turgor on the deformation of cell structural parameters is largely the same as in fresh tissue. But, under compression flaccid cells undergo much larger deformations compared to cells with higher turgor. Thus, turgor manipulation affects to a greater extent the deformation of cells in stored tissue, where the integrity of cell walls is diminished. In tensile tests, however, turgor has a more explicit effect on cell deformations in fresh tissue. Nevertheless, deformations in stored tissue are considerably smaller for both tests, which complies with the observations on micromechanical parameters.

Cellular deformations in length were closely related to strain measurements in both tests. But, the process of cell deformation was different. In tensile tests, individual cells undergo approx. the same percentage increase in length as the whole tissue sample, suggesting that the exerted load is evenly distributed over all cells. In compression tests, however, the complete tissue samples get considerably more compressed than the individual cells. It seems that the cells close to the grips are compressed before the surveyed cells in the middle of the 
sample. Compressive load is thus not evenly distributed within the sample, but proceeds from the outer cells to the middle of the sample.

\section{Conclusion}

In this work the effect of turgor on micromechanical properties of fresh and soft apples was studied. By placing the microtensile stage under a stereomicroscope it was possible to simultaneously observe the deformation of individual cells. We showed that cell structural parameters were homogenous throughout the used apples and not influenced by manipulation of turgor. Different mechanical behaviour of apple tissue was found in tensile and compressive loading. In general, the micromechanical properties failure stress and strain obtained in compression tests were considerably higher compared to tensile tests. No influence of turgor on failure stress could be found using tensile tests, but using compression an effect was found. In both tests, manipulation of turgor had a profound influence on strain at failure and stiffness at different strains. Cellular deformations in length and width were closely related to mechanical measurements. Under tensile loading cells become longer and thinner, and load is evenly distributed within the tissue. In compression tests, cells become shorter but wider, but collapse proceeds progressively starting from the exterior cells close to the grips. In our laboratory work is in progress to develop a detailed micromechanical model in order to describe the behaviour of plant tissue under mechanical stress. This work will be a valuable contribution for the development of these models.

\section{Acknowledgements}

The authors wish to thank the Fund for Scientific Research Flanders (F.W.O. Vlaanderen, project G.0200.02) and the European Union (Training Site Marie Curie Grant to M.L. Oey, project G056).

\section{Reference List}

Alamar, M.C., Zarzo, M., Suay, R., Moltó, E., Vanstreels, E., Verlinden, B.E., Nicolaï, B.M., Loodts, J., Tijskens, E., Ramon, H., 2005. Micromechanical behaviour of apple tissue in tensile and compression tests. FRUTIC05, Information and technology for sustainable fruit and vegetable production, 12-16.09.2005, Montpellier, France.

Alvarez, M.D., Saunders, D.E.J., Vincent, J.F.V., 2000. Fracture properties of stored fresh and osmotically manipulated apple tissue. Eur. Food Res. Technol. 211, 284-290.

Aguilera, J.M. and Stanley, D.W., 1999. Microstructural principles of food processing and engineering. Aspen Publishers, Gaithersburg.

Bajema, R.W., Hyde, G.M., Baritelle, A.L., 1998. Effects of mannitol on turgor and on failure stress and strain in potato tuber tissue. Postharvest Biol. Technol. 14, 199-205.

De Belie, N., Hallett, I.C., Harker, F.R., De Baerdemaeker, J., 2000. Influence of ripening and turgor on the tensile properties of pears: A microscopic study of cellular and tissue changes. J. Amer. Soc. Hort. Sci. 125(3), 350-356.

Hertog, M.L.A.T.M., Ben-Arie, R., Róth, E., Nicolaï, B.M., 2004. Humidity and temperature effects on invasive and non-invasive firmness measures. Postharvest Biol. Technol. 33, 79-91.

Jackman, R.L., Marangoni, AG., Stanley, D.W., 1992. The effetcs of turgor pressure on the puncture and viscoelastic properties on tomato tissue. J. Texture Studies 23, 491-505.

Konstankiewicz K. and Zdunek A., 2001. Influence of turgor and cell size on the cracking of potato tissue. Int. Agrophys. 15, 27-30. 
Kunzek, H., Kabbert, R, Gloyna, D., 1999. Aspects of material science in food processing: changes in plant cell walls of fruits and vegetables. Z. Lebensm. Unters. Forsch. A. 208, 233-250.

Lin, T.-T. and Pitt, R. E., 1986. Rheology of apple and potato tissue as affected by cell turgor pressure. J. Texture Studies 17, 291-313.

Nieto, A. B., Salvatori, D. M., Castro, M. A., Alzamora, S. M., 2004. Structural changes in apple tissue during glucose and sucrose osmotic dehydration: shrinkage, porosity, density and microscopic features. J. Food Eng. 61:269-278.

Salvatori, D.M. and Alzamora, S.M., 2000. Structural changes and mass transfer during glucose infusion of apples as affected by blanching and process variables. Drying Technol. 18, 21-48.

Scanlon, M.G., Pang, C.H., Biliaderis, C.G., 1996. The effect of osmotic adjustment on the mechanical properties of potato parenchyma. Food Res. Int. 29, 481-488.

Tu, K., Nicolaï, B., De Baerdemaeker, J., 2000. Effects of relative humidity on apple quality under simulated shelf temperature storage. Sci. Hort. 85, 217-229.

Vanstreels, E., Alamar, M.C., Verlinden, B.E., Enninghorst, A., Loodts, J.K.A., Tijskens, E., Ramon, H., Nicolaï, B.M., 2005. Micromechanical behaviour of onion epidermal tissue. Postharvest Biol. Technol. 37, 163-173

Varela, P., Salvador, A., Fiszman, S., 2005. Changes in apple tissue with storage time: Rheological, textural and microstructural analysis. J. Food Eng. In Press. 